\title{
Rheological studies of berry sauces with iodine-containing additives
}

\author{
Tamara Lystopad ${ }^{1}$, Grygorii Deinychenko' ${ }^{1}$, Vasyl Pasichnyi ${ }^{2}$, \\ Anastasiia Shevchenko' ${ }^{2}$, Yevhenii Zhukov ${ }^{3}$ \\ 1 - Kharkiv State University of Food Technology and Trade, Kharkiv, Ukraine \\ 2 - National University of Food Technology, Kyiv, Ukraine \\ 3 - Kharkiv College of Trade and Economics, Kyiv National University of Trade and \\ Economics, Kharkiv, Ukraine
}

Keywords:

Berry

Seaweed

Sauce

Iodine

Rheology

Article history:

Received

11.04 .2020

Received in revised

form 23.08.2020

Accepted

30.09.2020

Corresponding author:

Vasyl Pasichnyi

E-mail:

pasww1@ukr.net

DOI:

$10.24263 / 2304-$

974X-2020-9-3-13

\section{Abstract}

Introduction. The purpose of the research: to establish the influence of the addition of seaweed raw materials and the absence of structure-forming agent on the rheological parameters of berry sauces.

Materials and methods. Materials of rheological studies were samples of blueberry-cranberry sauce with guelder rose juice with different content of hydrated seaweed and control samples with modified corn starch and xanthan gum. The research of rheological properties was carried out rotational viscometer. Sensory research of sauces was performed on a fivepoint scale based on the weighting factor.

Results and discussion. The curves of the effective viscosity on the shear rate of the test specimens are similar to the curves of the control samples in all series of tests. The use of Fucus seaweed increases the viscosity of wild berry sauces without additional structuring agents compared to control samples made from xanthan gum, which is equal for samples with Fucus $-7.32 \mathrm{~Pa} \cdot \mathrm{s}$, with xanthan gum $-7.22 \mathrm{~Pa} \cdot \mathrm{s}$. The use of seaweed instead of xanthan gum and starch improves the ability of macroscopic systems to independently restore the structure after its destruction, as evidenced by relatively larger values of thixotropy coefficients, namely, the thixotropy coefficient for samples with xanthan gum is $-56.9 \%$, with starch $-64 \%$, with Laminaria $-78.0 \%$, with Undaria pinnatifida $-82.0 \%$. The use of seaweed improves the structural properties of pasteurized objects, which is confirmed by a decrease in the value of the coefficient of consistency, proportional to the viscosity of the sauce samples compared to non-pasteurized samples - for samples with Undaria pinnatifida by $0.84 \mathrm{~Pa} \cdot \mathrm{s}$, with Laminaria by $0,20 \mathrm{~Pa} \cdot \mathrm{s}$. Addition of up to $8 \%$ Laminaria and $3 \%$ Fucus and Undaria pinnatifida to hydrated algae does not have a negative effect on organoleptic and rheological parameters.

Conclusions. The possibility of production of berry sauces without additional addition of structure forming agents to the recipe is proved. 


\section{Introduction}

It is necessary to pay special attention to the structure and mechanical properties of the finished product when developing a quality sauce technology [2], in particular on vegetable raw materials [3]. As practice shows, in order to get a sauce with certain rheological properties, it is necessary to use structure-forming agent [1]. In the technologies of fruit and berry sauces, thickeners, for the most part, starches, gums etc., are the structure-forming agents [4]. Although most of them have a positive effect on the structural and mechanical properties of sauces and are widespread [5], they also have high calories and low digestibility [6]. Therefore, adding them only increases calories and does not increase the nutritional value of the product [7].

Currently, there are a number of developments of replace traditional thickeners in the production of sauce products [8]. Works on the use of modifications of starches [9-12] and composite mixtures have become the most widespread [13]. In addition, there are a number of developments that prove the feasibility of using thickeners of non-starch nature [15-19] and pectin substances [20] as structure forming agents.

However, during the analysis of existing developments, no studies were found that would confirm the possibility of not using additional thickeners in the production of berry sauces. Thus, the question of the possibility of producing sauces only on a natural basis remains unresolved.

It is known that the berry raw material contains a significant amount of pectin substances [21], which are able to have a structure-forming effect [22]. Therefore, it can be assumed that the additional introduction of thickeners in the formulations of berry sauces is not necessary. In this way, a product will be obtained that is characterized by naturalness and easily digestible.

The analysis of recent research and the relevance of the development of technology of sauces from wild and cultivated berries with the addition of iodine-containing additives has been described and proven in previous studies [23-25].

The purpose of the research: to establish the influence of the addition of seaweed raw materials and the absence of structure-forming agent on the rheological parameters of sauces.

To achieve this purpose, a number of tasks were formulated, namely:

- Development of sauce technology with high sensory quality indicators,

- To determine the effect of thickener on the viscosity,

- To determine the effect of thickener on the restoration of the structure,

- The effect of pasteurization on the viscosity of the objects of research.

\section{Materials and methods}

Materials of researches were samples of blueberry-cranberry sauce with guelder rose juice and control samples.

As the control samples, sauces of industrial production were used, namely blueberry sauce based on modified corn starch and cranberry sauce based on xanthan gum.

The technology of production of blueberry-cranberry sauce with guelder rose juice consists in mechanical culinary processing of initial raw materials, crushing of berries, preparation of seaweed raw materials, connection of components of mix, mixing before uniform distribution of components, thermal processing and pasteurization at a temperature of $98 \ldots 100^{\circ} \mathrm{C}$. The ratio of the main prescription components after mechanical culinary processing is bilberry puree: cranberry puree: guelder rose juice: sugar $=1: 1: 1 / 5: 1$. It should be noted that the developed technology does not use additional structure forming agent. The proposed sauce technology involves the use of dry seaweed. Since the hygroscopicity of seaweed is not the same, the optimal hydromodules are established: for Laminaria $-1: 5-1: 6$, for Undaria pinnatifida $-1: 8-1: 9$, for 
Fucus - 1:3-1:4. Namely, previous studies [26], which relied on iodine content in seaweed raw materials established the possibility of adding hydrated seaweed in quantities of 3,5 and $8 \%$ of the original recipe mass. The estimated amount of iodine in the finished sauces is $0.1-1.0 \mathrm{mg}$ per $100 \mathrm{~g}$ of the finished sauce, depending on the type of seaweed used. This sauce is completely natural and do not contain any additional structure forming components.

Samples were studied without the addition of seaweed raw materials and with the addition of Laminaria, Fucus and Undaria pinnatifida, which in the context of the studies can be conditionally taken into account by thickeners.

Even at the initial stage of rheological studies, it became apparent that sauce samples to which hydrated Laminaria was added to the composition showed a dependence of effective viscosity on the sliding velocity similar to the control samples. At the same time, the curves of the dependence of the effective viscosity on the sliding velocity of the test samples, to which 5 and 8\% hydrated Fucus and Undaria pinnatifida seaweed were added, have a different dynamics compared to the control specimens. Thus, due to the expediency of detecting the maximum amount of seaweed raw material that can be added to the sauce recipe, a series of studies with the content of hydrated seaweed Fucus and Undaria pinnatifida-3\% and Laminaria - 8\% are further described.

Order of research consisted of two main stages - sensory quality assessment and rheological research.

Sensory researches of sauces were performed on a five-point scale based on the weighting factor [27]. During the organoleptic analysis, the appearance, consistency, color, taste and smell were determined. For a more detailed study, each group of indicators was divided into segments. When assessing the appearance and consistency of the sauce, homogeneity, absence of inclusions, fluidity and density were determined. When assessing color - homogeneity, expressiveness, naturalness and intensity; taste - expressiveness, balance, speed of release, purity, naturalness; smell - expressiveness, compliance with the type of raw materials used, stability, purity.

The next stage of the research was to conduct rheological researches that would confirm the assumptions about the non-use of structure forming agent.

The research of rheological properties was carried out by an experimental method using «Reotest-2» rotational viscometer [28]. During the experiments for the sauce samples, the dependencies between the viscosity and the shear rate were recorded for different values of the strain rate from $0.3333 \mathrm{~s}^{-1}$ to $437.4 \mathrm{~s}^{-1}$ at $20^{\circ} \mathrm{C}$. All dependencies were recorded with increasing and decreasing velocity gradient, i.e. with forward and reverse strokes of the viscometer. The experimental conditions were as close as possible to the production conditions [29].

The effective (dynamic) viscosity of the test samples is generally described by the equation of the following form [30]:

$$
\eta_{e f}=B \cdot \gamma^{-m},
$$

where $\eta_{\mathrm{ef}}$ - effective viscosity, Pa.s, $B$ - coefficient of consistency proportional to the viscosity, $\mathrm{Pa} \cdot \mathrm{s}, \gamma$ - sliding velocity, $m$ - rate of destruction of the structure.

The thixotropy coefficient was calculated by the formula:

$$
\lambda_{m}=\frac{B_{3}}{B_{n}} \cdot 100,
$$

where $\lambda_{m}$ - thixotropy coefficient, $\% ; B_{3}-$ value of the coefficient of consistency proportional to the viscosity at reverse course, $\mathrm{Pa} \cdot \mathrm{s} ; B_{n}$ - value of the coefficient of consistency proportional to the viscosity at forward course, Pa. $\mathrm{s}$. 


\section{Results and discussion}

\section{Determination of sensory properties}

The first stage of the study was the conduct of sensory analysis, which allowed determining the patterns of formation of sensory indicators, as it is on these indicators that potential consumers, in the first place, evaluate the product.

Taking into account the influence on sensory quality indicators, the possible percentage of added hydrated seaweed to the prescription composition was investigated. In previous studies, we have identified that the addition of 3-8\% hydrated Laminaria, Fucus and Undaria pinnatifida does not worsen the sensory parameters [26]. The results of sensory analysis are shown in Table 1.

\section{Sensory analysis of sauces}

Table 1

\begin{tabular}{|c|c|c|c|c|c|c|}
\hline \multirow[t]{2}{*}{ Indicator } & \multirow{2}{*}{$\begin{array}{l}\text { Weighting } \\
\text { factor }\end{array}$} & \multirow{2}{*}{$\begin{array}{c}\text { Weighting } \\
\text { factor of } \\
\text { characteristic }\end{array}$} & \multirow[t]{2}{*}{ Characteristic } & \multicolumn{3}{|c|}{ Score, points } \\
\hline & & & & $\begin{array}{l}\text { Bilberry- } \\
\text { cranberry } \\
\text { sauce } \\
\text { with } \\
\text { guelder } \\
\text { rose juice }\end{array}$ & $\begin{array}{l}\text { Bilberry } \\
\text { sauce } \\
\text { with } \\
\text { Starch }\end{array}$ & $\begin{array}{l}\text { Cranberry } \\
\text { sauce } \\
\text { with } \\
\text { xanthan } \\
\text { gum }\end{array}$ \\
\hline \multirow[t]{2}{*}{ Appearance } & \multirow[t]{2}{*}{0,2} & 0,83 & Homogeneity & 4,80 & 4,80 & 4,90 \\
\hline & & 0,17 & $\begin{array}{l}\text { Absence of } \\
\text { inclusions }\end{array}$ & 4,80 & 4,70 & 4,70 \\
\hline \multicolumn{4}{|c|}{ Total score on the indicator } & 0,96 & 0,95 & 0,96 \\
\hline \multirow[t]{2}{*}{ Consistency } & \multirow[t]{2}{*}{0,25} & 0,4 & Fluidity & 4,90 & 4,70 & 4,80 \\
\hline & & 0,3 & Density & 4,70 & 4,80 & 4,70 \\
\hline \multicolumn{4}{|c|}{ Total score on the indicator } & 1,20 & 1,19 & 1,19 \\
\hline \multirow[t]{4}{*}{ Color } & \multirow[t]{4}{*}{0,15} & 0,3 & Homogeneity & 4,80 & 4,70 & 4,80 \\
\hline & & 0,2 & Expressiveness & 4,90 & 5,00 & 4,90 \\
\hline & & 0,2 & Intensity & 5,00 & 5,00 & 5,00 \\
\hline & & 0,3 & Naturalness & 5,00 & 4,90 & 4,90 \\
\hline \multicolumn{4}{|c|}{ Total score on the indicator } & 0,74 & 0,74 & 0,74 \\
\hline \multirow[t]{5}{*}{ Taste } & \multirow[t]{5}{*}{0,25} & 0,1 & Expressiveness & 5,00 & 4,70 & 4,80 \\
\hline & & 0,2 & Balance & 4,90 & 4,00 & 4,10 \\
\hline & & 0,1 & Speed of release & 4,80 & 4,00 & 3,90 \\
\hline & & 0,3 & Purity & 5,00 & 3,90 & 4,00 \\
\hline & & 0,3 & Naturalness & 5,00 & 3,90 & 3,80 \\
\hline \multicolumn{4}{|c|}{ Total score on the indicator } & 1,24 & 1,03 & 1,03 \\
\hline \multirow[t]{4}{*}{ Smell } & \multirow[t]{4}{*}{0,15} & 0,3 & Expressiveness & 4,90 & 4,80 & 4,90 \\
\hline & & 0,2 & $\begin{array}{l}\text { Compliance with } \\
\text { the type of raw } \\
\text { materials used }\end{array}$ & 4,90 & 3,70 & 4,90 \\
\hline & & 0,2 & Stability & 5,00 & 4,70 & 4,80 \\
\hline & & 0,3 & Purity & 5,00 & 4,00 & 3,90 \\
\hline \multicolumn{4}{|c|}{ Total score on the indicator } & 0,74 & 0,65 & 0,65 \\
\hline \multicolumn{4}{|c|}{ Common score } & 4,88 & 4,57 & 4,57 \\
\hline
\end{tabular}




\section{— Food Technology —}

The sauce recipe, which is made according to the proposed technology, does not include flavorings. Sauces are made only on a natural basis, which has a positive effect on sensory characteristics. As can be seen from the table, industrial samples of sauces, which include a significant number of additives, are almost not inferior to the developed sauces in terms of appearance, but significantly inferior in terms of taste and smell.

\section{Influence of the type of thickener on the viscosity of berry sauces}

The first series of research identified the effect of the type of thickener on the viscosity of the objects of research. The curves of the dependence of the effective viscosity of the test samples on the sliding velocity are shown in Figure 1.

The results of mathematical processing of the experimental data from Figure 1 are shown in Table 2.

The calculated values of the coefficients of determination $\left(\mathrm{R}^{2}\right)$ indicate the high reliability of the analytical equations that describe the behaviour of each of the test samples.

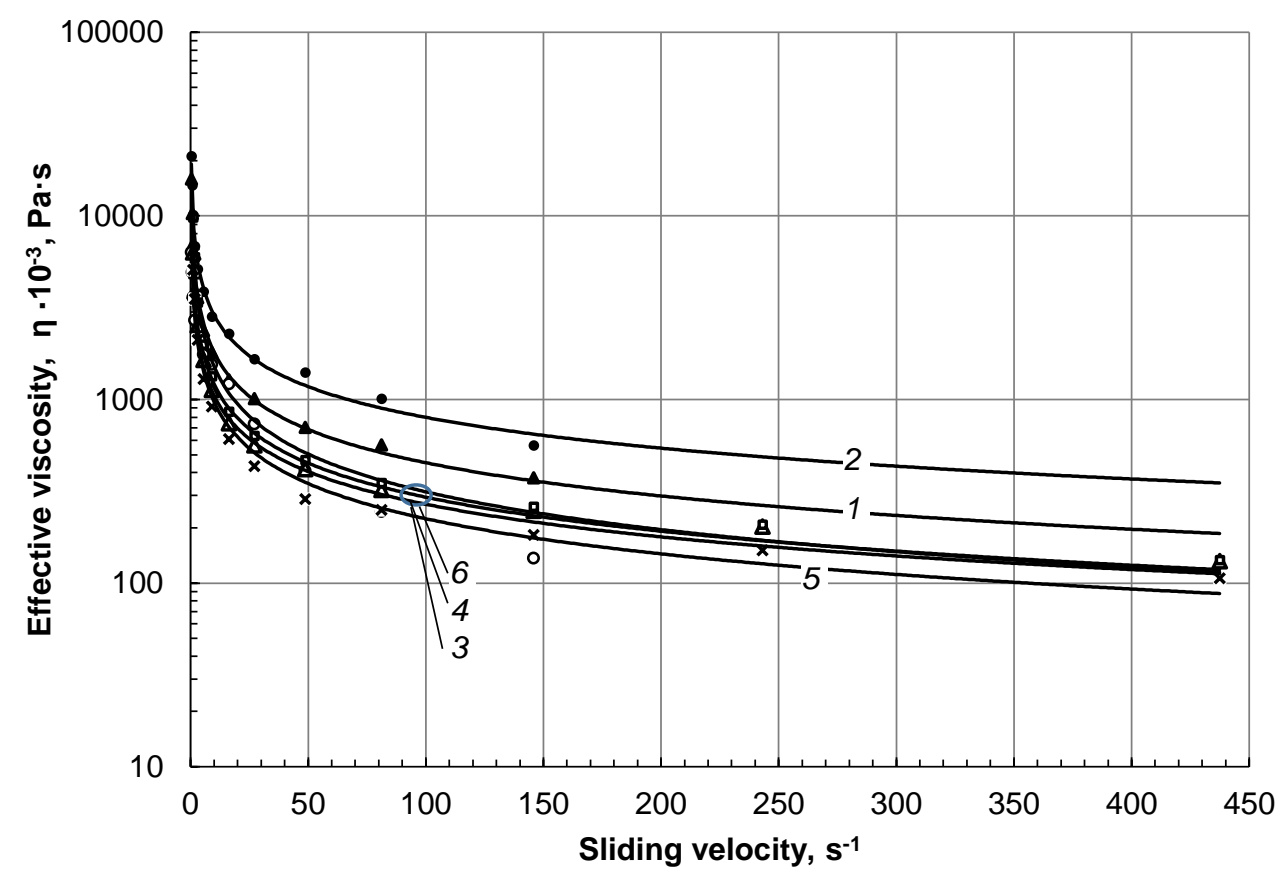

Figure 1. Dependence of the effective viscosity of the samples on the sliding velocity

1 - Sauce with Xanthan gum, 2 - Sauce with Starch, 3 - Sauce Without thickener, 4 - Sauce with Laminaria, 5 - Sauce with Undaria pinnatifida, 6-Sauce with Fucus 
Equation coefficients (1)

\begin{tabular}{|l|l|c|l|}
\hline Sample & $\boldsymbol{B , P a} \cdot \mathbf{s}$ & $\boldsymbol{m}$ & $\boldsymbol{R}^{\mathbf{2}}$ \\
\hline Sauce with Xanthan gum & 7,22 & 0,60 & 0,99 \\
\hline Sauce with Starch & 10,39 & 0,56 & 0,99 \\
\hline Sauce Without thickener & 4,09 & 0,59 & 0,96 \\
\hline Sauce with Laminaria & 5,00 & 0,62 & 0,99 \\
\hline Sauce with Undaria pinnatifida & 4,19 & 0,64 & 0,98 \\
\hline Sauce with Fucus & 7,32 & 0,68 & 0,98 \\
\hline
\end{tabular}

According to the decrease in the value of the coefficient of consistency proportional to the viscosity, the test samples can be arranged in the following ranked row: Sauce with Starch $\rightarrow$ Sauce with Fucus $\rightarrow$ Sauce with Xanthan gum $\rightarrow$ Sauce with Laminaria $\rightarrow$ Sauce with Undaria pinnatifida $\rightarrow$ Sauce Without thickener. As can be seen from the above data, the lowest coefficient of consistency is observed in the test samples without thickener and with Undaria pinnatifida. The largest is in samples with starch and Fucus. The values of the consistency coefficients of other samples occupy an intermediate position. It should be noted that using as a thickener Fucus increases the viscosity of the target products compared to Xanthan gums (the control sample).

According to the decrease in the value of the rate of destruction of the structure, the test samples can be arranged in the following ranked row: Sauce with Fucus $\rightarrow$ Sauce with Undaria pinnatifida $\rightarrow$ Sauce with Laminaria $\rightarrow$ Sauce with Xanthan gum $\rightarrow$ Sauce Without thickener $\rightarrow$ Sauce with Starch. Samples with starch and Without thickener are characterized by the lowest rate of structure destruct ion. The structure of samples with Fucus and Undaria pinnatifida is most rapidly destroyed.

The results obtained can be primarily explained by the chemical composition of berry and seaweed raw materials. It is known that the viscosity of products, in addition to pectin, is significantly affected by other polysaccharides, including alginates [31]. According to the literature, the highest content of alginate among these algae is in fucus, the lowest - in Undaria pinnate $[32,33]$. In addition, the viscosity can be affected by fucoidans, the content of which in Fucus is $9-11 \%$ on dry matter [34], in Laminaria - 2-4\% [35], in Undaria pinnatifida $-5-16 \%[36]$.

\section{Effect of thickener type on the restoration of the structure of berry sauces}

The second series of experiments was aimed at determining the effect of the type of thickener on the ability of macroscopic systems to self-restore the structure after its destruction. For this purpose, the viscosity of the samples was investigated using the "reverse course" method. The curves of the dependence of the effective viscosity of the test specimens from the sliding velocity at reverse course are shown in Figure 2. 


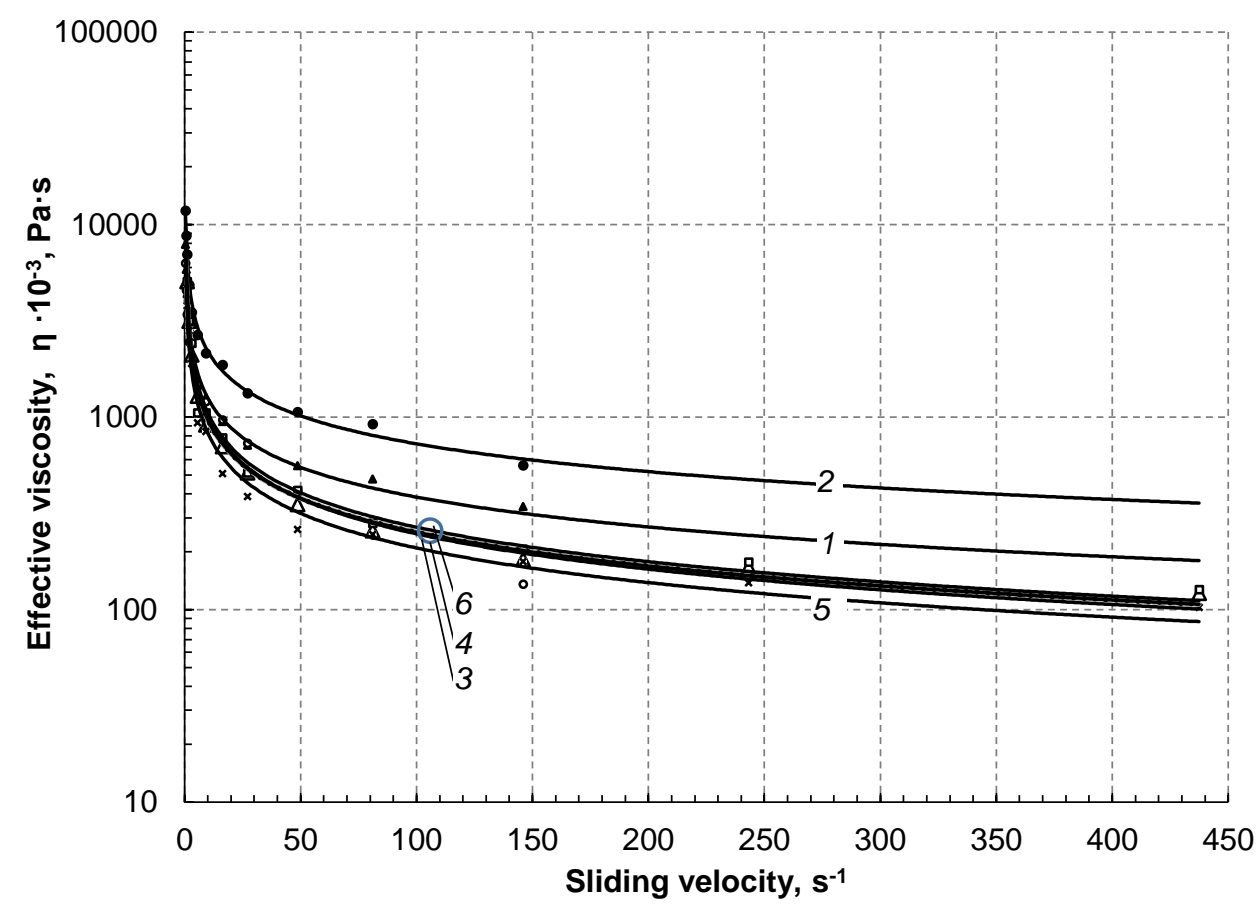

Figure 2. Dependence of the effective viscosity of the samples on the sliding velocity at reverse course

1 - Sauce with Xanthan gum, 2 - Sauce with Starch, 3 - Sauce Without thickener,

4 - Sauce with Laminaria, 5 - Sauce with Undaria pinnatifida, 6-Sauce with Fucus

The results of mathematical processing of the experimental data from Figure 2 are shown in Table 3.

\section{Equation coefficients at reverse course}

Table 3

\begin{tabular}{|l|l|l|l|}
\hline Sample & $\boldsymbol{B}, \mathbf{P a} \cdot \mathbf{s}$ & $\boldsymbol{m}$ & $\boldsymbol{R}^{\mathbf{2}}$ \\
\hline Sauce with Xanthan gum & 4,11 & 0,52 & 0,99 \\
\hline Sauce with Starch & 6,65 & 0,48 & 0,99 \\
\hline Sauce Without thickener & 3,22 & 0,56 & 0,93 \\
\hline Sauce with Laminaria & 4,10 & 0,61 & 0,99 \\
\hline Sauce with Undaria pinnatifida & 3,27 & 0,60 & 0,98 \\
\hline Sauce with Fucus & 4,14 & 0,60 & 0,98 \\
\hline
\end{tabular}

The calculated values of the coefficients of determination $\left(\mathrm{R}^{2}\right)$ indicate the high reliability of the analytical equations that describe the behavior of each of the test samples. 
According to the decrease in the value of the coefficient of consistency proportional to the viscosity, the test samples can be arranged in the following ranked row: Sauce with Starch $\rightarrow$ Sauce with Fucus $\rightarrow$ Sauce with Xanthan gum $\rightarrow$ Sauce with Laminaria $\rightarrow$ Sauce with Undaria pinnatifida $\rightarrow$ Sauce Without thickener. As can be seen from the above data, the properties of the samples at reverse course remain similar to those identified at forward course.

According to the decrease in the value of the rate of destruction of the structure, the test samples can be arranged in the following ranked row: Sauce with Laminaria $\rightarrow$ Sauce with Undaria pinnatifida $\rightarrow$ Sauce with Fucus $\rightarrow$ Sauce Without thickener $\rightarrow$ Sauce with Xanthan gum $\rightarrow$ Sauce with Starch. As can be seen from the above data, the properties of the test samples at reverse course have changed compared to the data obtained at forward course. The structure of samples with Laminaria and Undaria pinnatifida is most rapidly destroyed.

The data obtained are shown in Table 4.

Thixotropy coefficients (2)

Table 4

\begin{tabular}{|l|l|l|l|}
\hline Sample & $\boldsymbol{B}_{\boldsymbol{3}}, \mathbf{P a} \cdot \mathbf{s}$ & $\boldsymbol{B}_{\boldsymbol{n}}, \mathbf{P a} \cdot \mathbf{s}$ & $\lambda_{\boldsymbol{m}, \boldsymbol{\%}}$ \\
\hline Sauce with Xanthan gum & 4,11 & 7,22 & 56,9 \\
\hline Sauce with Starch & 6,65 & 10,39 & 64,0 \\
\hline Sauce Without thickener & 3,22 & 4,09 & 84,5 \\
\hline Sauce with Laminaria & 4,10 & 5,00 & 78,0 \\
\hline Sauce with Undaria pinnatifida & 3,27 & 4,19 & 82,0 \\
\hline Sauce with Fucus & 4,14 & 7,32 & 56,6 \\
\hline
\end{tabular}

According to the decrease in the value of the thixotropy coefficient, the test samples can be arranged in the following ranked row: Sauce Without thickener $\rightarrow$ Sauce with Undaria pinnatifida $\rightarrow$ Sauce with Laminaria $\rightarrow$ Sauce with Starch $\rightarrow$ Sauce with Xanthan gum $\rightarrow$ Sauce with Fucus. It should be noted that the use of seaweed thickeners instead of traditional thickeners improves the ability of macroscopic systems to self-repair the structure after its destruction.

The obtained results are in complete agreement with the data of parallel studies by IRspectroscopy to determine the chemical composition of raw materials, sauces and structural changes that occur with raw materials under the influence of technological factors. During these studies, it was found that seaweed raw materials contain amine and hydroxyl polar groups, which under the influence of technological factors interact and form intermolecular hydrogen bonds [37]. These groups of bonds have a positive effect on the structural properties of sauces.

\section{Influence of pasteurization on the viscosity of the developed sauces}

In the third series of exams, the effect of pasteurization on the viscosity of the sauces developed was researched. The curves of the dependence of the effective viscosity of the test samples on the shear rate after pasteurization are shown in Figure 3 


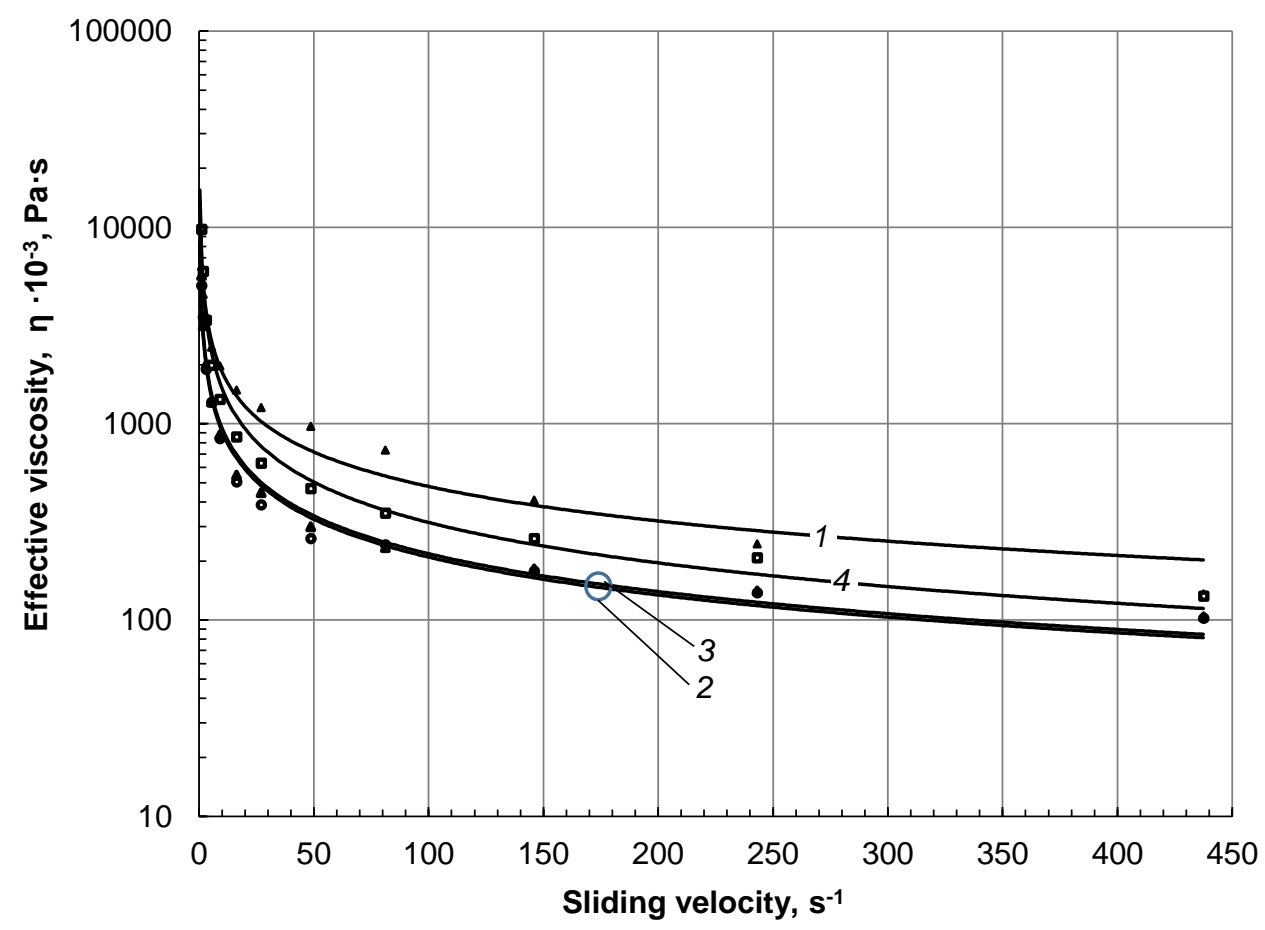

Figure 3. Dependence of the effective viscosity of the samples on the sliding velocity under the influence of pasteurization

1 - Sauce Without thickener, 2 - Sauce with Undaria pinnatifida, 3 -Sauce with Laminaria, 4 - Sauce with Fucus

The results of mathematical processing of the experimental data from Figure 3 are shown in Table 5.

The calculated values of the coefficients of determination $\left(R^{2}\right)$ indicate the high reliability of the analytical equations that describe the behavior of each of the test samples.

Effective viscosity of the test samples $\left(\eta \cdot 10^{-3}, \mathrm{~Pa} \cdot \mathrm{s}\right)$

Table 5

\begin{tabular}{|l|l|l|l|}
\hline Sample & $\boldsymbol{B}, \mathbf{P a} \cdot \mathbf{s}$ & $\boldsymbol{m}$ & $\boldsymbol{R}^{\mathbf{2}}$ \\
\hline Sauce Without thickener & 7,82 & 0,59 & 0,96 \\
\hline Sauce with Undaria pinnatifida & 3,99 & 0,64 & 0,98 \\
\hline Sauce with Laminaria & 4,16 & 0,64 & 0,98 \\
\hline Sauce with Fucus & 7,32 & 0,69 & 0,98 \\
\hline
\end{tabular}

According to the decrease in the value of the coefficient of consistency proportional to the viscosity, the test samples can be arranged in the following ranked row: Sauce with Fucus $\rightarrow$ Sauce Without thickener $\rightarrow$ Sauce with Laminaria $\rightarrow$ Sauce with Undaria pinnatifida. 
According to the decrease in the value of the rate of destruction of the structure, the test samples can be arranged in the following ranked row: Sauce with Fucus $\rightarrow$ Sauce with Undaria pinnatifida $\rightarrow$ Sauce with Laminaria $\rightarrow$ Sauce Without thickener. Sample Without thickener is characterized by the lowest rate of structure destruction.

To establish the qualitative and quantitative effect of pasteurization on the viscosity of the test samples, the indicators the coefficient of consistency proportional to the viscosity and the rate of destruction of the structure were summarized in Table 6 . The visualization of the analytical data is shown in Figure 4.

Influence of pasteurization on the viscosity of the test samples

Table 6

\begin{tabular}{|c|c|c|c|c|c|c|}
\hline \multirow[b]{2}{*}{ Sample } & \multicolumn{3}{|c|}{$\mathbf{B}, \mathbf{p a} \cdot \mathbf{s}$} & \multicolumn{3}{|c|}{$\mathbf{M}$} \\
\hline & & ¿ & 芯 & 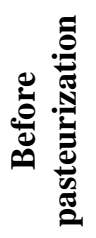 & そ & 苋 \\
\hline Sauce Without thickener & 10,39 & 7,82 & $-2,57$ & 0,56 & 0,58 & 0,02 \\
\hline Sauce with Laminaria & 4,19 & 3,99 & $-0,20$ & 0,64 & 0,64 & 0,00 \\
\hline Sauce with Undaria pinnatifida & 5,00 & 4,16 & $-0,84$ & 0,62 & 0,64 & 0,02 \\
\hline Sauce with Fucus & 7,32 & 7,32 & 0,00 & 0,68 & 0,68 & 0,01 \\
\hline
\end{tabular}

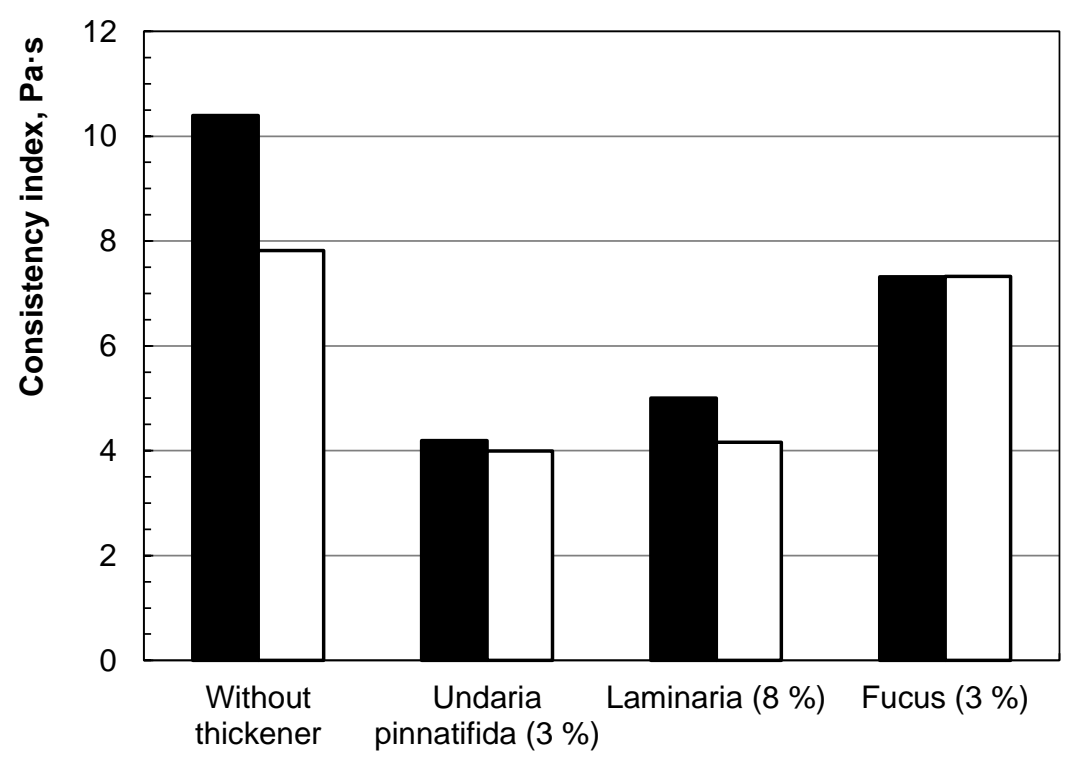

Figure 4. Effect of pasteurization on the coefficient of consistency proportional to the viscosity: - Before pasteurization; $\square-$ After pasteurization 


\section{Food Technology}

As can be seen from the above data, pasteurization causes a decrease in the consistency ratio of the viscosity for all test specimens except for Fucus sample. At the same time, the largest changes were set for samples without thickener - by $2.57 \mathrm{~Pa} \cdot \mathrm{s}$ (or by $25 \%$ ). Samples with Undaria pinnatifida and Laminaria lost 17 and 5\%, respectively. No change was observed for the sample with Fucus.

The increase in the values of the rate of destruction of the structure in the range of 1$4 \%$ is set for all experimental samples, except for the sample with Undaria pinnatifida. When using Laminaria as a thickener there is an increase of this indicator by $3 \%$, Fucus - by $1 \%$. No change was observed for the sample with Undaria pinnatifida.

The data obtained undoubtedly indicate that the use of seaweed as thickeners improves the structural properties of pasteurized objects of research. These changes can be explained by structural changes that occur with alginates under the action of elevated temperatures [38].

\section{Conclusions}

1. Samples of sauces, made by the developed technology without the addition of special structure-forming agents, have rheological dependencies, similar to analog samples, made with the addition of the most common structure-forming agents.

2. The use of some seaweed may increase the viscosity of the target products compared to the control samples

3. The use of seaweed thickeners instead of Xanthan gum improves the ability of macroscopic systems to self-repair the structure after its destruction.

4. The use of seaweed as thickeners improves the structural properties of pasteurized objects of research.

5. The possibility of producing berry sauces with iodine-containing additives without the addition of structure-forming agents to the formulation was proved.

\section{References}

1. Sikora M., Badrie N., Deisingh A.K., Kowalski S. (2008), Sauces and dressings: a review of properties and applications, Critical Reviews in Food Science and Nutrition, 48(1), pp. 50-77.

2. Sikora M., Kowalski S., Tomasik P., Sady M. (2007), Rheological and sensory properties of dessert sauces thickened by starch-xanthan gum combinations, Journal of Food Engineering, 79(4), pp. 1144-1151.

3. Krystyjan M., Sikora M., Adamczyk G., Tomasik P. (2012), Caramel sauces thickened with combinations of potato starch and xanthan gum, Journal of Food Engineering, 112 (1-2), pp. 22-28.

4. Mandala I.G., Savvas T.P., Kostaropoulos A.E. (2004), Xanthan and locust bean gum influence on the rheology and structure of a white model-sauce, Journal of Food Engineering, 64(3), pp. 335-342.

5. Kim S.G., Yoo W., Yoo B. (2014), Relationship between Apparent Viscosity and LineSpread Test Measurement of Thickened Fruit Juices Prepared with a Xanthan Gum-based Thickener, Preventive Nutrition and Food Science, 19(3), pp. 242-245.

6. Yalcinoz S.K., Ercelebi E. (2016), Rheological and sensory properties of red colored fruit sauces prepared with different hydrocolloids, Journal of International Scientific Publications: Agriculture and Food, 4 (1000020), pp. 496-509. 
7. Pasichnyj, V. M., Marynin, A. I., Moroz, O. O., \& Geredchuk, A. M. (2015), Rozrobka kombinovanyh bilkovozhyrovyh emul'sij dlja kovbas i napivfabrykativ z m'jasom ptyci. Vostochno-evropejskyj zhurnal peredovh tehnologyj, 6(73), pp. 32-38.

8. Andreeva S., Kolesnikova M. (2017), The Study of Thermodynamic Properties of Physical Modification Starches in The Production of Sweet Sauces, Food Science and Technology, 11(2), pp. 26-31.

9. Singh, N., Chawla, D., Singh, J. (2004), Influence of acetic anhydride on physicochemical, morphological and thermal properties of corn and potato starch, Food Chemistry, 86, pp. 601-608.

10. Lesław Juszczak, Zbigniew Oczadły, Dorota Gałkowska (2013), Effect of Modified Starches on Rheological Properties of Ketchup, Food and Bioprocess Technology, 6, pp. 1251-1260.

11. Sameh A. Korma, Kamal-Alhmad, Sobia Niazi, Al-Farga Ammar, Farah Zaaboul, Tao Zhang (2016), Chemically Modified Starch and Utilization in Food Stuffs, International Journal of Nutrition and Food Science, 5(4), pp. 264-272.

12. Rengsutthi K., Charoenrein S. (2011), Physico-chemical properties of jackfruite seed starch and its application as a thickener and stabilizer in chilli sauce, LWT-Food Science and Technology, 44 (5), pp. 1309-1313.

13. Sikora M., Kowalski S., Tomasik P., Sady M. (2007), Rheological and sensory properties of dessert sauces thickened by starch-xanthan gum combination, Journal of Food Engineering, 79, pp. 1144-1151.

14. Kravchenko M. F., Antonenko A.V. (2010), Kompozicijni sumishi z zernoproduktiv ECO u tehnologijah emul'sijnih harchovih produktiv, Naukovi praci ONUFT, 38(2), pp. 65-68.

15. Mandala I.G., Savvas T.P., Kostaropoulos A.E. (2004), Xanthan and locust bean gum influence on the rheology and structure of a white model-sauce, Journal of Food Engineering, 64(3), pp. 335-342.

16. Cho H.M., Yoo W., Yoo B (2012), Steady and dynamic rheological properties of thickened beverages used for dysphagia diets, The Food Science and Biotechnology, 21, pp. 17751779.

17. Dipjyoti S., Suvendu Bh. (2010), Hydrocolloids as thickening and gelling agents in food: a critical review, Journal of Food Science and Technology, 47, pp. 587-597

18. Sworn G. (2004), Hydrocolloid thickeners and their applications. Gums and Stabilizers for the Food Industry, Oxford: RSC Publishing, 12, pp. 13-22.

19. Krychkovska L. V., Anan'ieva V. V. (2015), Vykorystannia zahusnykiv nekrokhmalnoi pryrody $\mathrm{v}$ retsepturi emulsiinoho produktu funktsionalnoho pryznachennia, Visnyk NTU «KhPI», 7 (1116), pp. 83-88.

20. Ilina I.A., SapelnikovYu.A., Mironova O.P., Zemskova Z.G. (2003), Metodologicheskie osnovy processa kompleksoobrazovanija pektinov, Pishchevaya tekhnologiya, 7, pp. 35-38.

21. Robert A. B. (1997), Reassessment of Some Fruit and Vegetable Pectin Levels, Journal of Food Science, 62 (2), pp. 225-229.

22. Bélafi-Bakó, K., Cserjési, P., Beszédes, S., Csanádi, Z., Hodúr, C. (2012), Berry Pectins: Microwave-Assisted Extraction and Rheological Properties, Food and Bioprocess Technology, 5 (3), pp. 1100-1105.

23. Deynychenko G.V., Lystopad T.S., Kolisnychenko T.O. (2018), Obgruntuvannya dotsil'nosti vykorystannya vodorostevoyi syrovyny pry vyhotovlenni sousiv iz dykoroslykh ta kul'tyvovanykh yahid, Pratsi Tavriiskoho derzhavnoho ahrotekhnolohichnoho universytetu, 18 (1), pp. 29-36.

24. Deynychenko G., Lystopad T., Kolisnychenko T. (2019), Research of the safety indicators of berry sauces with seaweed's raw materials, Food science and technology, 13 (2), pp. 103 110. 


\section{Food Technology}

25. Deynychenko G., Lystopad T., Vishnikin A., Tamen A.-E. (2019), Vyznachennia vmistu yodu v laminarii ta zbahachenomu neiu yahidnomu sousi, Naukovi pratsi NUKhT, 25 (5), pp. 152-161.

26. Deynychenko G.V., Kolisnychenko T.O., Lystopad T.S. (2018), Rozrobka tekhnolohiyi yahidnykh sousiv z yodvmishchuyuchymy dobavkamy z urakhuvannyam yikh vplyvu na orhanoleptychni pokaznyky, Naukovyi visnyk Lvivskoho Natsionalnoho universytetu veterynarnoi medytsyny ta biotekhnolohii im.S.Z.Hzhytskoho, 20 (85), pp. 107-113.

27. Kantere V.M., Matison V.A., Fomenko M.A. (2003), Osnovnyye metody sensornoy otsenki produktov pitaniya, Pishchevaya promyshlennost', 10, pp. 6-13.

28. Špet'uchVojtech, Petrík Jozef, Grambalova Eva, Medved David, Palfy P, (2015), The capability of the viscosity measurement process, Acta Metallurgica Slovaca, 21 (10), pp. 53-60. DOI: 10.12776/ams.v21i1.471.

29. Holanda Natálya, Gomes Joyciane, SantosSandra, Damaceno Marlene. (2017), Shelf life of artisanal demi-glace sauce, Food Science and Technology, 38. DOI: 10.1590/1678457x.37416.

30. Horalchuk Andrii, (2006), Rheological methods of raw foods and automation of payments rheological characteristics. DOI: 10.13140/RG.2.1.2739.7847.

31. Magdalena Brzezińska, Grzegorz Szparaga (2015), The Effect Of Sodium Alginate Concentration On The Rheological Parameters Of Spinning Solutions. Autex Research Journal, 15 (2), pp. 123-126.

32. Misurcova, L. (2011) Chemical Composition of Seaweeds. Handbook of Marine Macroalgae, 7, pp. 171-192 doi: https://doi.org:10.1002/9781119977087.ch7.

33. Mabeau, S., Kloareg, B. (1987). Isolation and Analysis of the Cell Walls of Brown Algae: Fucus spiralis, F. ceranoides, F. vesiculosus, F. serratus, Bifurcaria bifurcata and Laminaria digitata. Journal of Experimental Botany, 38 (9), pp. 1573-1580, DOI: $10.1093 / \mathrm{jxb} / 38.9 .1573$.

34. Rodriguez-Jasso, R. M., Mussatto, S. I., Pastrana, L. (2014). Chemical composition and antioxidant activity of sulphated polysaccharides extracted from Fucus vesiculosus using different hydrothermal processes, 68, pp. 203-209. DOI: 10.2478/s11696-013-0430-9.

35. Adams, J. M., Ross, A. B., Anastasakis, K., Hodgson, E. M. et al. (2011). Seasonal variation in the chemical composition of the bioenergy feedstock Laminaria digitata for thermochemical conversion. Bioresource Technology, 102 (1), pp. 226-234 DOI: 10.1016/j.biortech.2010.06.152.

36. Hui, Z., Zunting, P., Chunchao, H. (2014) Undaria pinnatifida (Wakame): A Seaweed with Pharmacological Properties. Science International, 2 (2), pp. 32-36 DOI: 10.17311/sciintl.2014.32.36.

37. Deinychenko G., Lystopad T., Novik A., Chernushenko O., Farisieiev A., Matsuk Y., Kolisnychenko T. (2020), Identification of the content of macronutrients in berry sauces by IR spectroscopy. Eastern-European Journal of Enterprise Technologies, 5(107).

38. Magdalena Beata Łabowska, Izabela Michalak, Jerzy Detyna (2019), Methods of extraction, physicochemical properties of alginates and their applications in biomedical field - a review. Open Chemistry, 17(1), pp. 738-762, DOI: 10.1515/chem-2019-0077. 